\title{
Vaccination for hepatitis $\mathrm{C}$ virus: closing in on an evasive target
}

\author{
John Halliday ${ }^{1}$, Paul Klenerman ${ }^{2}$, and Eleanor Barnes ${ }^{\dagger, 2}$ \\ ${ }_{1}^{1}$ Translational Gastroenterology Unit, John Radcliffe Hospital, Oxford, UK \\ ${ }^{2}$ Peter Medawar Building for Pathogen Research and Oxford NIHR Biomedical Research Centre, \\ Nuffield Department of Medicine, University of Oxford, UK
}

\begin{abstract}
Hepatitis $\mathrm{C}$ virus (HCV) infects more than 170 million people globally and is a leading cause of liver cirrhosis, transplantation and hepatocellular carcinoma. Current gold-standard therapy often fails, has significant side effects in many cases and is expensive. No vaccine is currently available. The fact that a significant proportion of infected people spontaneously control HCV infection in the setting of an appropriate immune response suggests that a vaccine for $\mathrm{HCV}$ is a realistic goal. A comparative analysis of infected people with distinct clinical outcomes has enabled the characterization of many important innate and adaptive immune processes associated with viral control. It is clear that a successful HCV vaccine will need to exploit and enhance these natural immune defense mechanisms. New HCV vaccine approaches, including peptide, recombinant protein, DNA and vector-based vaccines, have recently reached Phase I/II human clinical trials. Some of these technologies have generated robust antiviral immunity in healthy volunteers and infected patients. The challenge now is to move forward into larger at-risk or infected populations to truly test efficacy.
\end{abstract}

\section{Keywords}

hepatitis $\mathrm{C}$ virus; immunity; prophylactic vaccine; T cells; therapeutic vaccine

\begin{abstract}
Hepatitis $\mathrm{C}$ virus (HCV) infects more than 170 million people globally with another 3 million people newly infected each year [1,2]. Following acute infection, $20 \%$ of people eradicate the virus over weeks or months and are often asymptomatic. The remaining $80 \%$ of people will develop chronic disease, of whom approximately $20 \%$ will eventually develop liver cirrhosis and 1-5\% will develop liver cancer [3-5]. HCV infection is now the leading cause for liver transplantation in the Western world. Disease prevalence varies by region, with the highest rates in parts of Asia and Africa where up to $20 \%$ of the population are infected [6]. The current treatment for $\mathrm{HCV}$ is pegylated interferon and ribavirin. This is expensive, prolonged, has an extensive side-effect profile and frequently fails. Clearly then, there is a real need for both a prophylactic vaccine that will prevent or attenuate primary infection, and also a therapeutic HCV vaccine that will increase cure rates of infected patients, and substantial progress has been made in this endeavor in recent years.
\end{abstract}

This article will first detail our current understanding of HCV infection, pathogenesis and treatment, and highlight the significant degree of viral diversity that presents a real challenge to vaccine development. Next we will review host-viral immune interactions and the broader challenges to the successful development of a vaccine. Finally, we will examine vaccine

\footnotetext{
(C) 2011 John Halliday, Paul Klenerman \& Eleanor Barnes

†Author for correspondence: Tel.: +44 187527 1199, Fax: +44 186528 1890, ellie.barnes@ndm.ox.ac.uk.
} 
approaches that have reached human clinical trials and present our vision of this rapidly moving field for the future.

\section{HCV diversity: implications for vaccine development}

Studies based on the molecular evolution of African and Asian HCVs suggest that HCV first appeared over 1000 years ago [7]. Subsequently, HCV evolved in discrete geographical regions giving rise to six distinct genotypes (1-6). These genotypes share a genetic homology of approximately $80 \%$ and are further subdivided into more than 100 subtypes $[8,9]$. In recent decades there has been a global epidemic of a few subtypes (1a, 1b, 3a, 2a and $4 \mathrm{a}$ ) associated with intravenous drug use (IVDU) and modern medical practice. The $\mathrm{HCV}$ genotype not only has relevance in relation to geographic distribution but more importantly in determining response to current medical therapy [10].

$\mathrm{HCV}$ is a particularly fastidious virus and has only been demonstrated reproducibly to replicate in the hepatocytes of humans and chimpanzees. It is a ssRNA virus with an enveloped virion belonging to the family Flaviviridae [11]. The positive-sense RNA genome is 9600 nucleotides in length. A single HCV polyprotein comprised of 3011 amino acids is translated from the genome and subsequently cleaved by cellular and viral proteases into three structural proteins (core, E1 and E2) and seven nonstructural (NS) proteins (p7, NS2, NS3, NS4A, NS4B, NS5A and NS5B) [12,13]. The envelope proteins mediate viral cell entry by binding to a number of cell surface receptors (e.g., low-density lipoprotein receptor, CD81, scavenger receptor B1 and claudin) [14].

$\mathrm{HCV}$ mutates at nearly one nucleotide per replication cycle as a consequence of the poor fidelity of the NS5B viral polymerase (which lacks proofreading function). This, in conjunction with a short viral half-life and rapid turnover (just a few hours), results in a high genetic variability. Consequently, many distinct but closely related HCV variants (known as quasispecies) are typically found in each infected individual [15]. It is estimated that HCV viral diversity is ten-times greater than that found in HIV infection and this clearly represents a significant challenge to successful vaccine development.

\section{The need for a therapeutic HCV vaccine}

Current gold-standard therapy for HCV infection is weekly subcutaneous injections of pegylated interferon (PEG-IFN) combined with daily oral ribavirin for a period of 24 weeks for genotypes 2 and 3, and 48 weeks for genotypes 1 and 4 . Therapy is fraught with significant side effects and leads to a sustained virological response (SVR; patients are negative for the virus by reverse transcription PCR 6 months after finishing therapy) in approximately $40-50 \%$ of patients with genotype 1 infection, $65-70 \%$ with genotype 3 and $80 \%$ of those with genotype 2. PEG-IFN and ribavirin treatment is also expensive and, at an average cost of approximately GB£7000 in the UK for a treatment course, is unaffordable in developing countries [16].

Two viral protease inhibitors (telaprevir and boceprevir) are currently in Phase III clinical trials for HCV and more are in development. These drugs will need concomitant PEG-IFN/ ribavirin therapy to avoid the rapid emergence of viral mutants and are currently only effective against genotype 1 infection. It is expected they will increase SVR rates following treatment to 70\% [17,18]. Because these drugs will be used together with PEG-IFN/ ribavirin, the cost of treatment will rise further and additional side effects, in particular skin rashes, can be anticipated. The cost of a 3-month course of protease inhibitor in the UK is currently predicted to be GB£18,000-22,000 [vertex pharmaceuticals, pers. сомm.]. Many other direct antiviral therapies are in development but these are unlikely to reach clinical application in the next few years. 
Interestingly, the SVR rate of individuals that are treated in the early phase of infection with IFN alone is very high (70-90\%) [19]. The reasons for this are not known but may relate to the fact that the infecting virus has not yet evolved to subvert the effects of IFN - or alternatively, that IFN therapy harnesses the host's robust natural immunity that is present in acute infection in a way that it is unable to do so once chronic infection is established.

Similarly, it is plausible that a therapeutic vaccination strategy may prove more efficacious in early infection. In clinical practice, however, acute infection is frequently asymptomatic and patients usually do not present to clinicians until chronic infection is established.

Clearly, a therapeutic vaccine that increases SVR rates in chronic infection, or reduces the duration of therapy would represent a major step forward.

\section{The need for a prophylactic HCV vaccine}

The need for a prophylactic HCV vaccine may be debated, since a change in social or cultural practices, such as the prevention of IVDU and the efficient screening of blood products and medical instruments worldwide would abort most new HCV infections. In practice, however, eradication through cultural change may be unachievable since the source of HCV infection is unclear (with no risk factors identified) in up to $20 \%$ of infected people, the prevention of IVDU has, to date, not been possible, and HCV is particularly prevalent in poorer countries where there is limited capacity for the financial investment required to reduce transmission during medical procedures.

\section{Antiviral host immunity: relevance to vaccine development}

Following acute infection with $\mathrm{HCV}$, approximately $20 \%$ of people will spontaneously clear the infection [4]. This is in stark contrast to HIV where infection inevitably persists. The distinct clinical outcomes that follow acute $\mathrm{HCV}$ infection allow comparative analysis of antiviral immunity between these clinical groups - this has been the major focus of many research groups over the last decade. Although the exact mechanisms behind successful viral clearance are still not yet fully elucidated, it appears that multiple components of the immune system, both innate and adaptive, play a crucial role in this process (Figure 1). A key observation is that strong, broad adaptive immune responses are detected during acute infection and these persist in those who resolve infection - whereas persistent infection is associated with a weak, frequently undetectable $\mathrm{HCV}$-specific T-cell response.

Is there any evidence, then, that the induction of adaptive immune responses during acuteresolved infection protects the host from subsequent viral challenge? If so, a HCV vaccine that mimics these responses may well afford protection. Findings from early seminal work demonstrated that chimpanzees that had recovered from $\mathrm{HCV}$ infection could be reinfected with the same inoculum $[20,21]$. However, we now have evidence that both chimpanzees and humans who have previously cleared $\mathrm{HCV}$ are at least partially protected against reinfection in the majority of cases [22-25]. Rather than preventing acute infection with sterilizing immunity, typically this form of protective immunity works by preventing progression to chronic infection following repeat $\mathrm{HCV}$ exposure. These findings suggest that a vaccine that induces and exploits similar immunogenic responses may ultimately succeed in preventing chronic HCV infection. Since chronic infection, and not acute infection, is associated with significant morbidity and mortality, prevention of chronicity is an acceptable end point.

\section{Anti-HCV-specific T-cell responses}

The HCV-specific T-cell response has been shown to play a crucial role in determining the outcome of primary HCV infection. First, comparative studies in man have demonstrated 
that a broad and sustained $\mathrm{CD} 8^{+}$and $\mathrm{CD} 4^{+} \mathrm{T}$-cell response targeting multiple $\mathrm{HCV}$ regions is associated with spontaneous viral clearance. Conversely, a weak and narrowly targeted Tcell response is a hallmark of persistent infection [26-30]. Second, immunogenetic studies from single-source outbreaks and from mixed populations have shown a clear association between different HLA class I and II alleles and viral clearance [31,32]. Both HLA B27 and $H L A A 3$ were shown to be protective against the development of chronic infection following an outbreak of HCV genotype 1b infection in Irish women in 1977. Third, evidence from the chimpanzee model has shown that once protective responses are induced, depletion of either $\mathrm{CD} 4^{+}$and $\mathrm{CD} 8^{+} \mathrm{T}$ cells leads to loss of control over repeated $\mathrm{HCV}$ challenge $[27,33]$.

In comparison to those who clear acute $\mathrm{HCV}$ infection, studies examining patients who develop chronic infection suggest that both the quality and quantity of their $\mathrm{CD} 4^{+}$and $\mathrm{CD} 8^{+}$ T-cell responses are impaired [34,35]. It is not yet clear, however, to what extent this is a cause or a consequence of chronic infection. Proposed mechanisms by which the T-cell response is attenuated include:

- Viral escape from T-cell recognition: T cells recognize short viral peptides (T-cell epitopes) bound in the groove of MHC molecules. In the presence of selective pressure driven by $\mathrm{T}$ cells, viral variation in T-cell epitopes that arise during viral replication may abrogate this recognition - so called 'viral escape'. To varying degrees, viral escape mutations may be associated with reduced viral fitness. T-cell escape in HCV infection has clearly been demonstrated such that many T-cell responses detected during chronic infection target a 'historical' epitope that is no longer found in circulating virus. However, in many cases $\mathrm{T}$ cells clearly do target autologous circulating virus - therefore, T-cell escape cannot fully explain the paucity of responses seen in chronic infection. This also means that therapeutic vaccination may be able to rescue responses that are still able to target the host's circulating virus;

- T-cell exhaustion: chronic antigen stimulation results in a reduction in antigenspecific T-cell frequency and function. This concept was first recognized in murine models of chronic viral infection. T-cell exhaustion is now thought to play a role in chronic HCV infection [36-39]. The mechanisms underlying exhaustion are poorly understood, but include expression of inhibitory receptors such as the molecules programmed death receptor-1 and cytotoxic T-lymphocyte-associated protein 4, which mediate T-cell function [40]. These receptors are normally involved in self tolerance, but in the setting of chronic infections may be upregulated, presumably to evade immunopathology. One of the key suggestions from murine models of persistent viral infection is that repair of these 'defective' T-cell responses is most readily achieved in the setting of a lowered viral load. Thus, the idea of vaccination or immunomodulation as an adjunct to conventional antiviral therapy has recently emerged;

- $\quad$ Regulatory immune cell subsets: Tregs $\left(\mathrm{FOXP}^{+}\right)$that may actively suppress $\mathrm{CD} 8^{+}$ and $\mathrm{CD}^{+} \mathrm{T}$-cell responses are increased in chronic $\mathrm{HCV}$ infection. Indeed, the depletion of Treg activity does lead to a consistent boost in T-cell function during HCV infection [41]. This may well be a consequence of chronicity rather than a cause, but nevertheless it may serve to limit the efficacy of immunotherapy unless it is reversed;

- Finally, the liver itself is thought to represent a tolerogenic environment. In evolutionary terms this would serve to protect the liver, which is constantly exposed to antigens via the portal tract, from chronic inflammation. Interestingly, in organ transplantation the liver is the only organ where HLA matching between 
donor and recipient is not required [42]. This observation raises the intriguing possibility that antiviral $\mathrm{T}$ cells primed in the periphery during vaccination may induce T cells that are of a 'superior' quality to those primed in the liver during natural infection.

\section{Humoral immunity towards HCV}

Circulating antibodies to HCV are usually detectable within 1-3 months of HCV infection [43] and appear to be an important component to viral control in early infection. There is a direct correlation between viral clearance during acute infection and the rapid induction of a high-titer of circulating cross-neutralizing antibodies [44]. However, neutralizing antibodies are also found in high titers in the majority of chronically infected patients and clearly, in these cases, are unable to control infection [45]. The envelope protein, which is the major target for HCV antibodies, displays some of the virus' highest levels of genetic heterogeneity. It is likely that variation between quasispecies in these envelope proteins allows the virus to evade host neutralizing antibodies [46]. This contrasts to other viruses such as the genetically stable hepatitis B virus in which persistent humoral immunity has allowed successful development of a preventative vaccine.

There are several other mechanisms by which HCV evades humoral immunity including direct cell-to-cell viral transfer [47], induction of antibodies that interfere with neutralizing antibodies $[46,48]$ and the shielding of neutralizing epitopes by glycosylation of defined amino acids of envelope glycoproteins [49]. For these reasons, it seems unlikely that an antibody-mediated vaccine in isolation will successfully induce sterilizing immunity, however, such a strategy may have an important role either as an adjunct with other approaches, or in attenuating the course of acute infection.

\section{Innate immunity}

The fact that IFN- $a$ forms the mainstay of treatment of HCV clearly demonstrates that innate immune cytokines can eradicate the virus. However, the mechanism of action of IFN is complicated, having both direct antiviral actions through the inhibition of protein kinase $\mathrm{R}$ and cellular protein production, and through diverse effects on immune cellular function. Although some early studies suggested that HCV-specific T-cell responses are enhanced by IFN [50,51], more recently, this has been challenged in studies that show that HCV-specific $\mathrm{T}$ cells and total T-cell counts decline in peripheral blood as treatment proceeds $[52,53]$. The reasons for this decline are unclear, but if they reflect a true failure of T-cell production, rather than migration, then therapeutic $\mathrm{T}$-cell vaccination strategies will need to overcome this.

Recent genome-wide association studies and candidate gene studies have further highlighted the crucial importance of innate immunity during HCV infection. These studies identified a cluster of seven host single-nucleotide genetic polymorphisms linked to IFN- $\lambda$ (also known as IL-28B) that are important in determining both spontaneous viral clearance during acute infection and also the response to standard PEG-IFN/ribavirin therapy [54-57]. Individuals homozygous for the protective alleles have viral clearance rates following treatment that are approximately three-times higher than those of patients who are homozygotes for the risk allele [56]. As yet, the causal genetic variant has not yet been identified. These observations have created intense interest in the field, and the biological role of IFN- $\lambda$ is currently under intense scrutiny. The mechanism by which IFN- $\lambda$ acts during HCV infection is not yet fully elucidated, although this cytokine clearly has direct antiviral actions in vivo and readily inhibits HCV replication in hepatoma cells (Huh-7.5) [58]. 
A Phase II human study of IFN- $\lambda$ for the treatment for HCV is currently underway [201], and while it is not yet known if this cytokine administered to patients will be of benefit, it is already clear that $\mathrm{HCV}$ vaccine studies will need to stratify patients according to IFN- $\lambda$ host genotype.

\section{The ideal vaccine}

\section{The requirements...}

Based on the viral-host interactions of $\mathrm{HCV}$ infection, as delineated in the previous sections, there are three characteristic properties that are likely to be shared by successful preventive and therapeutic vaccine approaches alike:

- These vaccines will need to deal with high levels of viral genetic diversity both between and within hosts - as such, vaccines that target relatively conserved viral regions will be required;

- The 'magnitude' of antiviral immunity associated with viral control is not precisely defined. Nevertheless, it is likely that a robust, broad and functional T cell, and possibly also a humoral, immune response will be required;

- Clearly, to be safe, a successful vaccine will need to eradicate HCV from the liver without inducing liver immunopathology. Human studies to date suggest that this is a realistic goal.

\section{....and the challenges}

In addition to overcoming the diverse mechanisms by which HCV evades immune clearance, there are practical obstacles that have hindered the development of both a preventive and therapeutic $\mathrm{HCV}$ vaccine. $\mathrm{HCV}$ is highly fastidious and there is no readily accessible animal model of infection. In 2003, study of viral entry and antibody-mediated neutralization was enabled for the first time through the development of retroviral particles pseudotyped with HCV envelope glycoproteins [59]. It was not until 2005 that a successful tissue model of HCV infection was developed [60]. This model uses the human hepatoma cell line Huh-7 and a unique viral variant capable of ongoing viral replication. This discovery allowed researchers to characterize the viral life cycle and viral-host interactions during infection for the first time. Transgenic mice expressing human MHC class I molecules have been used for specific HCV epitope ana lysis. Severe combined immunodeficieny (SCID) mouse models with chimeric human livers have been used to evaluate in vivo effects of antibodies to envelope glycoproteins [61].

To date, the only immunocompetent animal model for the pathogenesis or immune control of viral infection is the chimpanzee. This model has proved very useful in the preclinical phases of vaccine development since the immune mechanisms associated with viral control are broadly similar. For example, a study by Folgori was clearly able to demonstrate a reduction in $\mathrm{HCV}$ viremia, associated with the induction of robust immunity, using a small number of animals [62]. This study subsequently facilitated the use of adenoviral vector technology in human trials. However, there are practical, financial and, for some, ethical limitations in using these animals for research [63]. As a result, the small number of chimpanzees that can be used in HCV studies may limit the power of any conclusions that can be drawn.

Designing clinical studies in humans to evaluate a prophylactic vaccine is also challenging since the incidence of $\mathrm{HCV}$ infection in developed countries is relatively low other than in intravenous drug-using populations - targeting this patient group raises its own set of ethical and practical difficulties [64]. Large studies in developing countries where the incidence 
may be higher raises logistical difficulties. Assessing the efficacy of a prophylactic HCV vaccine will require large numbers of patients and careful followup, since acute infection is often asymptomatic. Furthermore, it is possible that a prophylactic vaccine may be unable to achieve sterilizing immunity. However, a vaccine that led to an attenuated course of acute infection associated with viral clearance may be sufficient to ultimately prevent chronic infection, as has been suggested by studies in the chimpanzee model [62]. In addition, this has study design implications; careful consideration must be given to the timing of IFN therapy during primary infection, in the context of a clinical study that is assessing vaccine efficacy. In theory, the vaccine may facilitate viral clearance weeks after current guidelines suggest IFN treatment should be given.

\section{Vaccine approaches: current status}

Over the last decade numerous HCV vaccine approaches have been assessed in mice and primates. Only a small fraction of animal $\mathrm{HCV}$ vaccine studies have progressed to human trials. The majority of these trials have evaluated potential therapeutic vaccines in HCVinfected patients. A smaller number have assessed vaccines in healthy volunteers; either with the aim of developing a prophylactic $\mathrm{HCV}$ vaccine or as a bridge to evaluating vaccine in $\mathrm{HCV}$-infected patients.

The question as to which HCV antigen a vaccine should target is a key one. The envelope region, which is essential for viral cell entry, may seem the obvious target for a prophylactic $\mathrm{HCV}$ antibody-inducing vaccine - but as discussed previously, the major antigenic determinants of the envelope protein are hypervariable both between, and within, infected individuals. Chimpanzee data have demonstrated that the induction of $\mathrm{HCV}$ envelope antibodies will afford protection with challenge with homologous viral strains only [65]. This view has been recently challenged using collated chimpanzee data that have demonstrated protection from heterologous viral strains (both genotype-1a) [66,67], and cross-genotype neutralizing antibodies have been demonstrated using a SCID mouse model transplanted with human hepatocytes [68]. A prophylactic vaccine that induces antienvelope immunity and attenuates the course of primary infection either alone, or in combination with other approaches, remains an attractive goal.

The HCV core protein might seem the obvious candidate for a therapeutic T-cell vaccine, since this is the most highly conserved region of the translated HCV genome both within, and between, different HCV genotypes. However, studies have shown that the core protein can interfere with innate and adaptive anti-HCV immune responses [69,70]. Furthermore, our own data suggests that in persistent infection, anticore $\mathrm{T}$-cell responses are frequently detected in the absence of viral escape, suggesting that these responses in particular are unable to control viral replication [71]. Many core-based DNA vaccines have been tested in small animal models, and clearly robust anticore cellular responses can be generated. However, a heterologous prime-boost (plasmidencoding DNA, boost with recombinant protein) vaccination strategy in chimpanzees vaccinated with core, E1, E2 and NS3 failed to induce any anticore responses [72].

For these reasons, the most recent strategies have focused on inducing T-cell responses to the NS HCV antigens, which are genetically conserved compared with the HCV envelope, and which are known to contain multiple $\mathrm{CD}^{+}$and $\mathrm{CD} 8^{+} \mathrm{T}$-cell epitopes [73].

Four main vaccine strategies have been investigated in human clinical studies: recombinant protein vaccines, peptide vaccines, DNA vaccines and vector vaccines. The advantages and limitations of each of these approaches, in combination with a summary of human trials in $\mathrm{HCV}$ vaccine development, will be outlined in the following sections. 


\section{Recombinant protein vaccines}

The use of recombinant proteins as potential vaccine candidates assumes that inducing an immune response to a limited number of viral epitopes is sufficient to develop protective immunity. The principle of this approach is to isolate the gene(s) encoding the appropriate protein and clone it in bacteria, yeast or mammalian cells. Recombinant proteins are prepared either from culture medium or transfected cells. While some recombinant proteins are sufficient in isolation to elicit a strong immune response, others require adjuvant therapy. Generally, protein-based approaches induce antibody and $\mathrm{CD} 4^{+} \mathrm{T}$-cell responses.

\section{Envelope protein vaccines}

The hepatitis B vaccine was the first successful recombinant protein vaccine used in humans. This vaccine employs a conserved hepatitis B surface antigen and is effective in preventing hepatitis B infection through the production of antibodies. By contrast, the genetic variability of the $\mathrm{HCV}$ viral envelope, which is the main target for anti-HCV antibodies, makes such an approach for a $\mathrm{HCV}$ vaccine challenging. Nevertheless, recognition that the presence of pre-existing antibodies to $\mathrm{HCV}$ envelope proteins is associated with a better response to PEG-IFN therapy [74], and that anti-envelope antibodies can lead to an attenuated course of primary infection [75], has led to therapeutic and prophylactic vaccine studies, respectively, which aim to induce anti-envelope antibodies.

Prophylactic vaccine-The only published clinical trial of a prophylactic vaccine for HCV utilized a recombinant E1/E2 heterodimer adjuvanted with adjuvant MF59C (an oil-inwater emulsion) [76]. This placebo-controlled, dose-escalation Phase I study evaluated the vaccine in 60 healthy subjects. All subjects developed neutralizing antibodies and T-cell lymphocyte proliferation responses to E1/E2 and an inverse response to increasing amounts of antigen was noted. The vaccine was well tolerated. The study authors suggest that larger clinical trials to evaluate vaccine efficacy are indicated.

Therapeutic vaccines-The first candidate therapeutic vaccine for HCV was administered to humans in 2003 (Table 1) [77,78]. The vaccine consisted of a recombinant HCV-E1 protein in alum adjuvant. It was administered over 6 months via multiple injections to 20 healthy, and 34 chronically infected, treatment-naive patients. The vaccine induced $\mathrm{HCV}$-specific antibody and T-cell responses in both patient groups (50 out of 54). Assessment of efficacy showed no change in HCV RNA levels but, in some subjects, improvements in liver histology were seen; a total of $24 \mathrm{HCV}$-infected patients underwent liver biopsies before and after vaccination. In nine of these patients there was histological improvement after 17 months. The observed increase in anti-E1 antibody levels correlated with improvement in liver histological scores and reduction in serum alanine transaminase levels (a measure of liver inflammation).

As a result, this work progressed to a placebo-controlled, multicenter trial (presented in abstract form in 2008 [79]) that evaluated 122 patients who received four courses of six injections over 3 years. Humoral and cellular immune responses to the E1 protein were induced but vaccination did not prevent histological progression of liver disease [79]. Innogenetics, the company investigating this vaccine, ceased its program in 2008 and no further work has been published.

\section{Core proteins}

Heat-killed yeast cells (Saccharomyces cervisiae) expressing conserved core-NS3 fusion protein have been trialed as a therapeutic vaccine candidate (GI5005) [80]. In a Phase II, placebo-controlled trial, GI5005 was combined with standard therapy (PEG-IFN/ ribavirin) in 66 chronic HCV-1 patients. The protocol consisted of a 12-week run-in of standard 
therapy, followed by weekly doses for 5 weeks followed by monthly doses for 2 months of GI5005 vaccine, administered subcutaneously. Prior nonresponders received 72 weeks of standard therapy while treatment-naive patients received 48 weeks. No data on immunological response have been published. The investigators report an increase in SVR rates in patients homozygous for the IFN- $\lambda$ risk alleles [81]. Published peer-reviewed data are awaited.

A vaccine using conserved $\mathrm{HCV}$ core protein with an adjuvant composed of saponin, cholesterol and phospholipid, called ISCOMATRIX®, has been evaluated in a Phase I trial of 30 healthy volunteers [82]. The vaccine was safe and all eight volunteers who received the highest dose $(50 \mu \mathrm{g})$ developed a specific humoral response to the core protein. However, $\mathrm{HCV}$-specific $\mathrm{CD} 8^{+} \mathrm{T}$ cells could only be detected in two patients. Further studies are planned by the same investigators to evaluate this approach as a therapeutic vaccine in $\mathrm{HCV}$-infected patients.

\section{Peptide vaccines}

Like recombinant protein vaccines, peptide-based vaccines are well tolerated (Table 2). They induce HCV-specific T-cell immunity through the direct presentation of vaccine peptide to the T-cell receptor via HLA molecules. However, the major limitation of this approach is that peptide vaccines are HLA-specific and, as such, coverage will be restricted to a subset of the population. Additionally, HCV peptide vaccines to date have included only a handful of peptides - and the breadth of the induced T-cell response may be insufficient to control infection. In addition, some peptides may potentially induce tolerance of effector cells or Treg cells rather than inducing immunity [83].

IC41 is a peptide vaccine currently in clinical development. It consists of five synthetic peptides from core, NS3 and NS4 proteins that are conserved across HCV genotypes 1 and 2 , combined with the adjuvant poly-L-arginine. The peptides include three $\mathrm{CD} 4^{+} \mathrm{T}$-cell and five $H L A A 2$-restricted $\mathrm{CD}^{+}$T-cell HCV epitopes. In a Phase II, double-blind study, this vaccine was administered subcutaneously to $36 H L A A 2$ patients with genotype 1 chronic HCV infection who had previously been nonresponsive to PEG-IFN/ribavirin and compared with 24 controls [84]. The vaccine was well tolerated with no serious adverse events. Weak HCV-specific T-cell proliferative and IFN-g enzyme-linked immunosorbent spot (ELISpot) responses were observed in 67 and $42 \%$ of patients, respectively. Three responders with the strongest IFN-g-secreting T-cell response had a transient decline in serum RNA ( $>1 \log$ ). A subsequent Phase II study combined IC41 with PEG-IFN/ribavirin therapy in 35 patients with HCV genotype 1 infection. T-cell responses were observed in $73 \%$ of vaccinated patients and associated with higher rates of viral clearance [85]. The lack of an unvaccinated control arm makes it difficult to draw any significant conclusion regarding vaccine efficacy.

More recently, biweekly intradermal IC41 administration was found to induce stronger Tcell responses compared with the original monthly subcutaneous injection approach [86]. This optimized vaccine schedule has been tested in 50 patients with chronic hepatitis C. A significant decline in viral load was observed after 4 months according to results currently presented in abstract form only [87]. Intercell AG (Austria, Vienna), the company developing IC41, recently announced plans for a Phase II trial to begin in 2011 that will combine IC41 with nitazoxanide (a new broad-spectrum antiviral drug [88,89]) in 60 treatment-naive genotype-1-infected $\mathrm{HCV}$ patients.

In 2009, a peptide derived from HCV core region (C35-44) was evaluated in a Phase I, dose-escalation, Japanese study of 26 patients (23 nonresponders to PEG-IFN/ribavirin and three who had declined standard therapy) [90]. A series of six biweekly subcutaneous injections was sufficient to induce peripheral peptide-specific $\mathrm{CD} 8^{+}$activity in 15 out of 25 
patients (measured with ELISpot) and 12 injections augmented peptide-specific IgG production. A greater than $30 \%$ improvement in alanine transaminase was observed in seven out of 24 patients and two patients had a $>1 \log$ reduction in viral load. Further evaluation with a Phase II study is under consideration.

Another Japanese study adopted a 'personalized' peptide vaccine approach. In this study, 12 patients with HCV-1b, who had previously failed PEG-IFN/ribavirin therapy, were administered four $\mathrm{CD} 8^{+} \mathrm{A} 24$ peptides in combination with Freund's adjuvant. Only those peptides that induced an immune response in each individual following the first vaccine dose were then administered fortnightly for another 14 vaccinations [91]. At the first assessment (following seven vaccine doses), the majority of patients had developed peptidespecific T-cell responses. A dose-dependent decrease in serum alanine transaminase and HCV RNA levels was observed in five and three patients, respectively.

A novel method of peptide delivery using autologous monocytederived dendritic cells was recently explored in a small Australian study [92]. Dendritic cells were first harvested and then loaded and activated ex vivo with HLA A2 1-restricted T-cell epitopes. Six patients chronically infected with HCV who had previously failed PEG-IFN/ribavirin therapy received the vaccine. All patients developed weak de novo $\mathrm{HCV}$-specific $\mathrm{CD} 8^{+} \mathrm{T}$-cell responses (measured by IFN- $\gamma$ ELISpot assays). The authors hypothesize that T-cell responses induced to viral epitopes not included in the vaccine may have been caused by epitope spreading. There was no change in viral load or anti-HCV core antibody levels and T-cell responses were not sustained.

Finally, a Phase I, placebo-controlled trial assessing a virosome-based vaccine containing NS3 peptides has recently been completed but no data have been released [202].

In summary, peptide-based vaccines are well tolerated and able to induce weak peptidespecific T-cell and humoral responses. Efficacy needs to be optimized, as trials show a significant reduction in viral load in only a few patients.

\section{DNA vaccines}

In 2001, the first DNA vaccine was licensed for use to protect horses from West Nile virus [93]. Initial work in the decade leading up to this significant accomplishment demonstrated that injection of a plasmid containing a gene could effectively result in protein expression in vivo and subsequently induce a host immune response [94-96]. Substantial research efforts have been aimed at developing an effective hepatitis C DNA vaccine (Table 3) [97].

Unfortunately, the initial success observed with DNA vaccination-induced immunity in mice did not translate well into similar results in humans - probably, in part, because the efficacy of DNA uptake and gene expression decreases as the size of the immunized host grows $[98,99]$. Subsequently, several methods were developed to improve DNA delivery and hence immunogenicity. These methods include:

- Biolistic technology (biological ballistic or 'gene gun'): tungsten particles are loaded with genetic material and, using a device known as a particle gun, fired at living plant cells [100]. This resulted in delivery of DNA into a proportion of plant cells. In 2000, a clinical trial using a gene gun for DNA vaccination against hepatitis B was performed with successful induction of protective humoral immunity as well as hepatitis B surface antigen-specific T-cell responses [101];

- Electroporation (EP): electrical impulses create transient pores in living cells and subsequently allow delivery of DNA across the cell membrane. The local damage to cell membranes is also thought to enhance the local inflammatory response 
[102-104]. EP, at least in mice, is said to enhance the immunogenic response by DNA vaccination tenfold. This method has been successfully used in DNA vaccine trials in prostate cancer and is currently under evaluation in a Phase I/II HCV trial [105].

The first DNA-based vaccine to reach clinical trial for HCV infection did not employ either of these adjuvant vaccine delivery techniques. This Phase I trial based in Cuba evaluated a vaccine (CICGB-230) combining plasmid expressing HCV structural antigens (core/E1/E2) with recombinant core protein (Co.120) [106]. A total of 15 patients with HCV genotype-1 infection who had previously failed PEG-IFN/ribavirin therapy received monthly intramuscular injections for 6 months. The vaccine was well tolerated. The T-cell response to the vaccine components (as well as NS3) was measured using ELISpot and proliferation assays 1 month following the final vaccine. Although low levels of T-cell immunity were observed in 11 patients, others showed a reduction in responses. Six patients developed weak de novo neutralizing antibody responses against heterologous viral pseudoparticles. Only one patient had a drop in viral load of $>1 \log _{10}$. In addition, the authors reported stabilization or improvement in liver histology, however, the absence of a control arm makes this finding difficult to interpret.

The second HCV DNA-based vaccine (ChronVac-C, Tripep) to reach human trials employed electroporation to enhance the immunogenicity of intramuscular injection of plasmid expressing HCV antigens NS3/4a. Extensive codon modification was undertaken to allow effective DNA expression and enhance in vivo T-cell responses. A total of 12, treatment-naive, genotype-1 HCV-infected patients with a low viral load $(<800,000 \mathrm{IU} / \mathrm{ml})$ received four monthly doses of DNA (three groups: 167, 500 and $1500 \mu \mathrm{g}$ ) in this Phase I/ IIa clinical trial. Preliminary results from this trial were reported in 2009 [105]. A total of $67 \%$ (four out of six) of patients who received the higher doses had reductions in viral load exceeding $0.5 \log _{10}$ lasting for 2 to more than 10 weeks, with corresponding activation of Tcell responses in three of these patients. No severe adverse reactions were observed.

\section{Vector vaccines}

The use of viral vectors for the delivery of HCV RNA is an appealing vaccine choice. Adenoviral vectors have shown to be potent inducers of HCV-specific T-cell responses in the chimpanzee model and to reduce peak HCV viremia during primary infection [62]. This approach may induce a broader range of viral epitopes than a peptide-based approach since the immunogen contained within the vaccine is not HLA restricted.

Modified vaccinia Ankara (MVA) is a highly attenuated poxvirus strain that has been used safely in several vaccine designs for conditions such as HIV, colorectal cancer, TB and melanoma. A therapeutic vaccine (TG4040) using MVA that expresses NS3/4/5B proteins has been evaluated for safety and immunogenicity in an open-label, multicenter, doseescalation study (Table 4). Preliminary results were presented at the European Association for the Study of Liver Disease conference in 2009 [107]. A total of 15 chronically infected $\mathrm{HCV}$ patients received three weekly injections, nine of whom received a fourth injection at 6 months. In six out of 15 patients, a decline in HCV viral load (0.5-1.4 $\left.\log _{10}\right)$ was observed in association with a significant $\mathrm{CD}^{+} \mathrm{T}$-cell response. A Phase II trial using the vaccine in combination with standard treatment is planned [203].

Adenovirus vectors are also being employed in a Phase I vaccine trial to deliver NS HCV proteins (NS3-5B) to 36 healthy volunteers [204]. The vaccine vectors are genetically modified so that they are unable to replicate and the polymerase activity of the NS proteins is inactivated to further enhance vaccine safety. To overcome the problem of pre-existing anti-adenoviral anti-bodies, which may limit vector efficacy, two adenoviral vectors to 
which humans are rarely exposed are used: Ad6 and a simian vector AdCh3. Early data from this trial were presented at the American Association for the Study of Liver Disease in 2009 where this approach was reported to be highly immunogenic in healthy volunteers following a single priming injection (Ad6) [73]. Further studies are planned in HCV-infected patients.

\section{Future vaccine approaches}

Novel future vaccine approaches include virus-like particle (VLP)-based vaccines that have been successfully employed for viral infections such as hepatitis B $[108,109]$. A HCV VLP vaccine approach could facilitate delivery of neutralizing antibody- and core-specific T-cell epitopes in a single construct resembling mature HCV virions. In theory, the delivery of important antigenic determinants in this form rather than as linear recombinant protein or synthetic peptides could enhance immunity.

Additional strategies include molecules that induce innate immune responses, with secondary effects on adaptive responses (such as TLR-9 ligands [110]) that are either encoded within a vaccine construct or used as a vaccine adjuvant.

\section{Expert commentary}

Progress in our understanding of HCV pathogenesis and the treatment of infected patients is remarkable given that HCV was discovered only 21 years ago. Nevertheless, current goldstandard therapy (IFN/ribavirin) is ineffective in 30-50\% of patients depending on viral genotype. Direct antivirals (protease inhibitors) will be available in the clinic in the next 2 years. These will increase viral clearance rates in genotype-1 patients in particular.

However, these novel agents will be given in combination with IFN/ribavirin, costs will be prohibitive in many countries, and treatment will remain ineffective in approximately $30 \%$ of patients overall. So, while the authors welcome the addition of these drugs to the anti$\mathrm{HCV}$ therapeutic armory, a $\mathrm{HCV}$ vaccine that prevented or increased the cure rates when treating infected patients remains an attractive goal.

The challenges in developing a prophylactic and a therapeutic vaccine overlap but are not identical. The diversity of the HCV genome is a significant challenge to vaccine development and may be greater once chronic infection is established. Similarly, the ability of HCV to subvert and evade antiviral immunity increases over time. Indeed, a hallmark of chronic $\mathrm{HCV}$ infection is a weak and narrowly focused $\mathrm{HCV}$-specific T-cell response. The challenge to developing a successful therapeutic vaccination strategy will be to safely recover these responses and to broadly target circulating viral strains.

The fact that a significant proportion of acutely infected patients spontaneously eradicate infection in association with robust antiviral immunity suggests that the development of a prophylactic vaccine is an attainable goal. The ability to compare hosts who spontaneously clear HCV infection with those who develop persistent disease has allowed characterization of many important innate and adaptive immune processes that determine outcome. Although a broad $\mathrm{CD}^{+}$and $\mathrm{CD} 8^{+} \mathrm{T}$-cell response is clearly important in clearing infection, humoral and innate immune responses also play an important part in this complex and dynamic process, and a single 'correlate of protection' has not been defined. It is, however, clear that a successful prophylactic HCV vaccine will need to exploit and enhance these natural immune defense mechanisms. Some of the challenges to prophylactic HCV vaccine development are the assessment of efficacy in clinical studies. In Western countries with the infrastructure and finance needed to support large clinical trials, the 'HCV at-risk population' are those who abuse intravenous drugs, and assessment of this cohort is not easy. 
Significant advances in genomics and proteomics in recent years have enabled a variety of new HCV vaccine approaches to reach clinical trials. Peptide, recombinant protein, DNA and vector-based vaccines have all been explored with varying degrees of success.

Recombinant protein vaccines that induce anti-envelope antibody responses are unlikely to provide sterilizing immunity owing to the genetic variability of the HCV envelope regionbut may yet play a role in attenuating the course of primary infection or serve as an adjunct to a T-cell-based vaccine. Peptide and protein-based T-cell vaccines have induced weak Tcell responses only - this approach is likely to only progress with the development of novel adjuvants. DNA vaccines with additional techniques to enhance delivery and immunogenicity show some promise and have been shown to decrease viral load in some chronically infected patients. Adenoviral vectors appear to be highly immunogenic in healthy volunteers and Phase II studies in at-risk populations are required to assess efficacy. The effects of these vectors in HCV-infected patients is not yet known.

Ultimately, since HCV infection can be cleared by an appropriate immune response vaccination remains a realistic goal.

\section{Five-year view}

There are several promising vaccine trials currently recruiting patients that will undoubtedly further expand our understanding of the complex interplay of HCV and host immunity and our ability to modulate this in favor of the host. New therapeutic HCV vaccine approaches are likely to continue to be explored in combination with standard medical therapy rather than in isolation. The new directly acting viral protease inhibitors that will become available in the next few years will further influence this process. While these drugs will improve treatment outcomes for patients with HCV genotype-1 infection, their high cost will limit availability. Approaches for nongenotype-1 strains also need some consideration given the major genetic divergence of the six major genotypes and their distinct immunoreactivity.

Vaccines that produce substantial antiviral T-cell responses are being developed, but in the absence of a clear correlate of protection, efficacy will need to be demonstrated in welldesigned clinical trials. The organization and monitoring of these is a substantial issue for the field, but moves to harmonize studies of at-risk and acutely infected cohorts might accelerate this process.

\section{Key issues}

- Hepatitis $\mathrm{C}$ virus (HCV) infects more than 170 million people globally and is now the leading cause of liver transplantation worldwide.

- A total of $20 \%$ of acute HCV infections in humans will clear spontaneously clearance is associated with some degree of (but not complete) protective immunity.

- Current gold-standard treatment is prolonged, fraught with side effects, often ineffective and prohibitively expensive in developing countries.

- The host T-cell response is most important in determining the outcome of acute HCV infection but humoral and innate immune responses are also important.

- During chronic HCV infection, the host HCV-specific T-cell response is impaired - whether this is a consequence or a cause of chronic infection is not known.

- HCV has a remarkable ability to evade the natural host immune response through a number of mechanisms including genetic variation. 
- It is unlikely that sterilizing immunity can be obtained through vaccination, but a vaccine that attenuates the course of primary infection may afford protection from chronic carriage.

- Many promising vaccine approaches have reached clinical trials including peptide, protein, DNA and vector-based vaccines.

- A successful T-cell vaccine strategy will need to induce a broad and strong Tcell response. Adenoviral vectors are highly immunogenic in healthy volunteers; it is not yet known if these vaccines can adequately recover $\mathrm{T}$-cell responses in $\mathrm{HCV}$-infected patients.

- Well-characterized cohorts of at-risk and acutely infected HCV patients are required to move Phase I vaccine studies forward into studies of efficacy.

\section{Acknowledgments}

Financial \& competing interests disclosure

Eleanor Barnes is funded by the Medical Research Council (MRC) UK and the Oxford NIHR Biomedical Research Centre. John Halliday is funded by the MRC UK and Paul Klenerman is funded by the Wellcome Trust UK. The authors are currently working on Phase I HCV vaccine studies using adeno-viral vectors in collaboration with an industrial partner Okairos. The authors have no other relevant affiliations or financial involvement with any organization or entity with a financial interest in or financial conflict with the subject matter or materials discussed in the manuscript apart from those disclosed.

No writing assistance was utilized in the production of this manuscript.

\section{References}

Papers of special note have been highlighted as:

•• of considerable interest

1. WHO. Hepatitis C: global prevalence. Wkly Epidemiol. Rec. 1997; 72(46):341-344. [PubMed: 9385865]

2. EASL Clinical Practice Guidelines: management of cholestatic liver diseases. J. Hepatol. 2009; 51(2):237-267. [PubMed: 19501929]

3. Lauer GM, Walker BD. Hepatitis C virus infection. N. Engl. J. Med. 2001; 345(1):41-52. [PubMed: 11439948]

4. Afdhal NH. The natural history of hepatitis C. Semin. Liver Dis. 2004; 24(Suppl. 2):3-8. [PubMed: 15346240]

5. Tong MJ, el-Farra NS, Reikes AR, Co RL. Clinical outcomes after transfusion-associated hepatitis C. N. Engl. J. Med. 1995; 332(22):1463-1466. [PubMed: 7739682]

6. Alter MJ. Epidemiology of hepatitis C virus infection. World J. Gastroenterol. 2007; 13(17):24362441. [PubMed: 17552026]

7. Pybus OG, Barnes E, Taggart R, et al. Genetic history of hepatitis $C$ virus in East Asia. J. Virol. 2009; 83(2):1071-1082. [PubMed: 18971279]

8. Simmonds P, Bukh J, Combet C, et al. Consensus proposals for a unified system of nomenclature of hepatitis C virus genotypes. Hepatology. 2005; 42(4):962-973. [PubMed: 16149085]

9. Simmonds P. Viral heterogeneity of the hepatitis C virus. J. Hepatol. 1999; 31(Suppl. 1):54-60. [PubMed: 10622561]

10. Manns MP, Wedemeyer H, Cornberg M. Treating viral hepatitis C: efficacy, side effects, and complications. Gut. 2006; 55(9):1350-1359. [PubMed: 16905701]

11. Moradpour D, Penin F, Rice CM. Replication of hepatitis C virus. Nat. Rev. Microbiol. 2007; 5(6): 453-463. [PubMed: 17487147] 
12. Reed KE, Rice CM. Overview of hepatitis C virus genome structure, polyprotein processing, and protein properties. Curr. Top. Microbiol. Immunol. 2000; 242:55-84. [PubMed: 10592656]

13. Grakoui A, Wychowski C, Lin C, Feinstone SM, Rice CM. Expression and identification of hepatitis C virus polyprotein cleavage products. J. Virol. 1993; 67(3):1385-1395. [PubMed: 7679746]

14. Flint M, Quinn ER, Levy S. In search of hepatitis C virus receptor(s). Clin. Liver Dis. 2001; 5(4): 873-893. [PubMed: 11685799]

15. Bukh J, Miller RH, Purcell RH. Genetic heterogeneity of hepatitis C virus: quasispecies and genotypes. Semin. Liver Dis. 1995; 15(1):41-63. [PubMed: 7597443]

16. Grieve R, Roberts J, Wright M, et al. Cost effectiveness of interferon a or peginterferon a with ribavirin for histologically mild chronic hepatitis C. Gut. 2006; 55(9):1332-1338. [PubMed: 15994216]

17. Kwo PY, Lawitz EJ, McCone J, et al. Efficacy of boceprevir, an NS3 protease inhibitor, in combination with peginterferon $\mathrm{a}-2 \mathrm{~b}$ and ribavirin in treatment-naive patients with genotype 1 hepatitis C infection (SPRINT-1): an open-label, randomised, multicentre Phase 2 trial. Lancet. 2010; 376(9742):705-716. [PubMed: 20692693]

18. Marcellin P, Forns X, Goeser T, et al. Telaprevir is effective given every 8 or 12 hours with ribavirin and peginterferon $\mathrm{a}-2 \mathrm{a}$ or $2 \mathrm{~b}$ to patients with chronic hepatitis C. Gastroenterology. 2011; 140(2):459-468. [PubMed: 21034744]

19. Wiegand J, Buggisch P, Boecher W, et al. Early monotherapy with pegylated interferon $\mathrm{a}-2 \mathrm{~b}$ for acute hepatitis C infection: the HEP-NET acute-HCV-II study. Hepatology. 2006; 43(2):250-256. [PubMed: 16440367]

20. Farci P, Alter HJ, Govindarajan S, et al. Lack of protective immunity against reinfection with hepatitis C virus. Science. 1992; 258(5079):135-140. [PubMed: 1279801]

21. Prince AM, Brotman B, Huima T, Pascual D, Jaffery M, Inchauspe G. Immunity in hepatitis C infection. J. Infect Dis. 1992; 165(3):438-443. [PubMed: 1538149]

22. Osburn WO, Fisher BE, Dowd KA, et al. Spontaneous control of primary hepatitis C virus infection and immunity against persistent reinfection. Gastroenterology. 2010; 138(1):315-324. [PubMed: 19782080]

23. Bassett SE, Guerra B, Brasky K, et al. Protective immune response to hepatitis C virus in chimpanzees rechallenged following clearance of primary infection. Hepatology. 2001; 33(6): 1479-1487. [PubMed: 11391537]

24. Nascimbeni M, Mizukoshi E, Bosmann M, et al. Kinetics of $\mathrm{CD}^{+}{ }^{+}$and $\mathrm{CD} 8^{+}$memory T-cell responses during hepatitis $\mathrm{C}$ virus rechallenge of previously recovered chimpanzees. J. Virol. 2003; 77(8):4781-4793. [PubMed: 12663785]

25. Mehta SH, Cox A, Hoover DR, et al. Protection against persistence of hepatitis C. Lancet. 2002; 359(9316):1478-1483. [PubMed: 11988247]

26. Wertheimer AM, Miner C, Lewinsohn DM, Sasaki AW, Kaufman E, Rosen HR. Novel CD4 ${ }^{+}$and $\mathrm{CD}^{+} \mathrm{T}$-cell determinants within the NS3 protein in subjects with spontaneously resolved HCV infection. Hepatology. 2003; 37(3):577-589. [PubMed: 12601356]

27. Grakoui A, Shoukry NH, Woollard DJ, et al. HCV persistence and immune evasion in the absence of memory T cell help. Science. 2003; 302(5645):659-662. [PubMed: 14576438]

28. Diepolder HM, Zachoval R, Hoffmann RM, et al. Possible mechanism involving T-lymphocyte response to non-structural protein 3 in viral clearance in acute hepatitis $\mathrm{C}$ virus infection. Lancet. 1995; 346(8981):1006-1007. [PubMed: 7475549] •• The first paper demonstrating that the T-cell response is crucial in determining outcome of acute hepatitis $\mathrm{C}$ virus (HCV) infection.

29. Thimme R, Oldach D, Chang KM, Steiger C, Ray SC, Chisari FV. Determinants of viral clearance and persistence during acute hepatitis C virus infection. J. Exp. Med. 2001; 194(10):1395-1406. [PubMed: 11714747]

30. Schulze zur Wiesch J, Lauer GM, Day CL, et al. Broad repertoire of the CD4 ${ }^{+}$Th cell response in spontaneously controlled hepatitis $\mathrm{C}$ virus infection includes dominant and highly promiscuous epitopes. J. Immunol. 2005; 175(6):3603-3613. [PubMed: 16148104] 
31. McKiernan SM, Hagan R, Curry M, et al. Distinct MHC class I and II alleles are associated with hepatitis C viral clearance, originating from a single source. Hepatology. 2004; 40(1):108-114. [PubMed: 15239092]

32. Neumann-Haefelin C, Thimme R. Impact of the genetic restriction of virus-specific T-cell responses in hepatitis C virus infection. Genes Immun. 2007; 8(3):181-192. [PubMed: 17230195]

33. Shoukry NH, Grakoui A, Houghton M, et al. Memory CD8 ${ }^{+} \mathrm{T}$ cells are required for protection from persistent hepatitis C virus infection. J. Exp. Med. 2003; 197(12):1645-1655. [PubMed: 12810686]

34. Lauer GM, Barnes E, Lucas M, et al. High resolution analysis of cellular immune responses in resolved and persistent hepatitis C virus infection. Gastroenterology. 2004; 127(3):924-936. [PubMed: 15362047]

35. Bowen DG, Walker CM. Adaptive immune responses in acute and chronic hepatitis $\mathrm{C}$ virus infection. Nature. 2005; 436(7053):946-952. [PubMed: 16107834]

36. Barber DL, Wherry EJ, Masopust D, et al. Restoring function in exhausted CD8 T cells during chronic viral infection. Nature. 2006; 439(7077):682-687. [PubMed: 16382236]

37. Gruener NH, Lechner F, Jung MC, et al. Sustained dysfunction of antiviral CD8 ${ }^{+}$T lymphocytes after infection with hepatitis C virus. J. Virol. 2001; 75(12):5550-5558. [PubMed: 11356962]

38. Urbani S, Boni C, Missale G, et al. Virus-specific CD8 ${ }^{+}$lymphocytes share the same effectormemory phenotype but exhibit functional differences in acute hepatitis B and C. J. Virol. 2002; 76(24):12423-12434. [PubMed: 12438568]

39. Wedemeyer H, He XS, Nascimbeni M, et al. Impaired effector function of hepatitis C virusspecific $\mathrm{CD}^{+} \mathrm{T}$ cells in chronic hepatitis C virus infection. J. Immunol. 2002; 169(6):3447-3458. [PubMed: 12218168]

40. Blackburn SD, Shin H, Haining WN, et al. Coregulation of $\mathrm{CD}^{+} \mathrm{T}$ cell exhaustion by multiple inhibitory receptors during chronic viral infection. Nat. Immunol. 2009; 10(1):29-37. [PubMed: 19043418]

41. Ward SM, Fox BC, Brown PJ, et al. Quantification and localisation of FOXP3 ${ }^{+}$T lymphocytes and relation to hepatic inflammation during chronic HCV infection. J. Hepatol. 2007; 47(3):316-324. [PubMed: 17475362]

42. Poli F, Scalamogna M, Aniasi A, et al. A retrospective evaluation of HLA-A, B and -DRB1 matching in liver transplantation. Transpl. Int. 1998; 11(Suppl. 1):S347-S349. [PubMed: 9665013]

43. Schmilovitz-Weiss H, Levy M, Thompson N, Dusheiko G. Viral markers in the treatment of hepatitis B and C. Gut. 1993; 34(Suppl. 2):S26-S35. [PubMed: 7686114]

44. Pestka JM, Zeisel MB, Blaser E, et al. Rapid induction of virus-neutralizing antibodies and viral clearance in a single-source outbreak of hepatitis C. Proc. Natl Acad. Sci. USA. 2007; 104(14): 6025-6030. [PubMed: 17392433]

45. Bartosch B, Bukh J, Meunier JC, et al. In vitro assay for neutralizing antibody to hepatitis C virus: evidence for broadly conserved neutralization epitopes. Proc. Natl Acad. Sci. USA. 2003; 100(24): 14199-14204. [PubMed: 14617769]

46. von Hahn T, Yoon JC, Alter H, et al. Hepatitis C virus continuously escapes from neutralizing antibody and T-cell responses during chronic infection in vivo. Gastroenterology. 2007; 132(2): 667-678. [PubMed: 17258731]

47. Timpe JM, Stamataki Z, Jennings A, et al. Hepatitis C virus cell-cell transmission in hepatoma cells in the presence of neutralizing antibodies. Hepatology. 2008; 47(1):17-24. [PubMed: 17941058]

48. Zhang P, Zhong L, Struble EB, et al. Depletion of interfering antibodies in chronic hepatitis C patients and vaccinated chimpanzees reveals broad cross-genotype neutralizing activity. Proc. Natl Acad. Sci. USA. 2009; 106(18):7537-7541. [PubMed: 19380744]

49. Helle F, Goffard A, Morel V, et al. The neutralizing activity of anti-hepatitis C virus antibodies is modulated by specific glycans on the E2 envelope protein. J. Virol. 2007; 81(15):8101-8111. [PubMed: 17522218] 
50. Kamal SM, Fehr J, Roesler B, Peters T, Rasenack JW. Peginterferon alone or with ribavirin enhances HCV-specific CD4 T-helper 1 responses in patients with chronic hepatitis C. Gastroenterology. 2002; 123(4):1070-1083. [PubMed: 12360469]

51. Cramp ME, Rossol S, Chokshi S, Carucci P, Williams R, Naoumov NV. Hepatitis C virus-specific $\mathrm{T}$-cell reactivity during interferon and ribavirin treatment in chronic hepatitis $\mathrm{C}$. Gastroenterology. 2000; 118(2):346-355. [PubMed: 10648463]

52. Barnes E, Gelderblom HC, Humphreys I, et al. Cellular immune responses during high-dose interferon-a induction therapy for hepatitis C virus infection. J. Infect Dis. 2009; 199(6):819-828. [PubMed: 19434929]

53. Burton JR Jr, Klarquist J, Im K, et al. Prospective analysis of effector and regulatory CD4 ${ }^{+} \mathrm{T}$ cells in chronic HCV patients undergoing combination antiviral therapy. J. Hepatol. 2008; 49(3):329338. [PubMed: 18644644]

54. Suppiah V, Moldovan M, Ahlenstiel G, et al. IL28B is associated with response to chronic hepatitis C interferon-a and ribavirin therapy. Nat. Genet. 2009; 41(10):1100-1104. [PubMed: 19749758]

55. Tanaka Y, Nishida N, Sugiyama M, et al. Genome-wide association of IL28B with response to pegylated interferon-a and ribavirin therapy for chronic hepatitis C. Nat. Genet. 2009; 41(10): 1105-1109. [PubMed: 19749757]

56. Thomas DL, Thio CL, Martin MP, et al. Genetic variation in IL28B and spontaneous clearance of hepatitis C virus. Nature. 2009; 461(7265):798-801. [PubMed: 19759533]

57. Ge D, Fellay J, Thompson AJ, et al. Genetic variation in IL28B predicts hepatitis C treatmentinduced viral clearance. Nature. 2009; 461(7262):399-401. [PubMed: 19684573]

58. Marcello T, Grakoui A, Barba-Spaeth G, et al. Interferons a and 1 inhibit hepatitis C virus replication with distinct signal transduction and gene regulation kinetics. Gastroenterology. 2006; 131(6):1887-1898. [PubMed: 17087946]

59. Bartosch B, Dubuisson J, Cosset FL. Infectious hepatitis C virus pseudo-particles containing functional E1-E2 envelope protein complexes. J. Exp. Med. 2003; 197(5):633-642. [PubMed: 12615904]

60. Heller T, Saito S, Auerbach J, et al. An in vitro model of hepatitis C virion production. Proc. Natl Acad. Sci. USA. 2005; 102(7):2579-2583. [PubMed: 15701697]

61. Mercer DF, Schiller DE, Elliott JF, et al. Hepatitis C virus replication in mice with chimeric human livers. Nat. Med. 2001; 7(8):927-933. [PubMed: 11479625]

62. Folgori A, Capone S, Ruggeri L, et al. A T-cell HCV vaccine eliciting effective immunity against heterologous virus challenge in chimpanzees. Nat. Med. 2006; 12(2):190-197. [PubMed: $16462801] \bullet$ The first study to demonstrate that a HCV T-cell vaccine, using adenoviral vectors, can protect chimpanzees from a heterologous viral challenge.

63. Bettauer RH. Chimpanzees in hepatitis C virus research: 1998. J. Med. Primatol. 2010; 39(1):9-23. [PubMed: 19900169]

64. Maher L, White B, Hellard M, et al. Candidate hepatitis C vaccine trials and people who inject drugs: challenges and opportunities. Vaccine. 2010; 28(45):7273-7278. [PubMed: 20831914] •• This recent paper explores the biological, methodological and ethical challenges facing HCV vaccine trials with particular focus on the intravenous drug-using population.

65. Farci P, Shimoda A, Wong D, et al. Prevention of hepatitis C virus infection in chimpanzees by hyperimmune serum against the hypervariable region 1 of the envelope 2 protein. Proc. Natl Acad. Sci. USA. 1996; 93(26):15394-15399. [PubMed: 8986822] •• Early study showing that high titers of anti-HCV antibodies can give protection from HCV infection.

66. Houghton M, Abrignani S. Prospects for a vaccine against the hepatitis C virus. Nature. 2005; 436(7053):961-966. [PubMed: 16107836]

67. Houghton M. Prospects for prophylactic and therapeutic vaccines against the hepatitis $C$ viruses. Immunol. Rev. 2011; 239(1):99-108. [PubMed: 21198667]

68. Law M, Maruyama T, Lewis J, et al. Broadly neutralizing antibodies protect against hepatitis C virus quasispecies challenge. Nat. Med. 2008; 14(1):25-27. [PubMed: 18064037] 
69. Sarobe P, Lasarte JJ, Zabaleta A, et al. Hepatitis C virus structural proteins impair dendritic cell maturation and inhibit in vivo induction of cellular immune responses. J. Virol. 2003; 77(20): 10862-10871. [PubMed: 14512536]

70. Large MK, Kittlesen DJ, Hahn YS. Suppression of host immune response by the core protein of hepatitis C virus: possible implications for hepatitis C virus persistence. J. Immunol. 1999; 162(2): 931-938. [PubMed: 9916717]

71. Semmo N, Barnes E, Taylor C, et al. T-cell responses and previous exposure to hepatitis $\mathrm{C}$ virus in indeterminate blood donors. Lancet. 2005; 365(9456):327-329. [PubMed: 15664228]

72. Rollier C, Depla E, Drexhage JA, et al. Control of heterologous hepatitis C virus infection in chimpanzees is associated with the quality of vaccine-induced peripheral T-helper immune response. J. Virol. 2004; 78(1):187-196. [PubMed: 14671100]

73. Barnes E, Folgori A, Aston S. Phase I trial of a highly immunogenic T-cell vacine for HCV based on novel adenoviral vectors from rare serotypes. Hepatology. 2009; 50 Suppl.(4):105A.

74. Depraetere S, Van Kerschaever E, Van Vlierberghe H, et al. Long term response to interferon treatment in chronic hepatitis $\mathrm{C}$ patients is associated with a significant reduction in anti-E1 envelope antibody titers. J. Med. Virol. 2000; 60(2):126-132. [PubMed: 10596010]

75. Choo QL, Kuo G, Ralston R, et al. Vaccination of chimpanzees against infection by the hepatitis C virus. Proc. Natl Acad. Sci. USA. 1994; 91(4):1294-1298. [PubMed: 7509068]

76. Frey SE, Houghton M, Coates S, et al. Safety and immunogenicity of HCV E1E2 vaccine adjuvanted with MF59 administered to healthy adults. Vaccine. 2010; 28(38):6367-6373. [PubMed: 20619382]

77. Leroux-Roels G, Depla E, Hulstaert F, et al. A candidate vaccine based on the hepatitis C E1 protein: tolerability and immunogenicity in healthy volunteers. Vaccine. 2004; 22(23-24):30803086. [PubMed: 15297058]

78. Nevens F, Roskams T, Van Vlierberghe H, et al. A pilot study of therapeutic vaccination with envelope protein E1 in 35 patients with chronic hepatitis C. Hepatology. 2003; 38(5):1289-1296. [PubMed: 14578869]

79. Wedemeyer H, Mazur W, Nevens F. Factors influencing progression of liver fibrosis in patients with chronic hepatitis C: results of the 3-year T2S-918-HCV study with HCVE1 therapeutic vaccine. J. Hepatol. 2008; 48:S27-S28.

80. Habersetzer F, Baumert TF, Stoll-Keller F. GI-5005, a yeast vector vaccine expressing an NS3core fusion protein for chronic HCV infection. Curr. Opin. Mol. Ther. 2009; 11(4):456-462. [PubMed: 19649991]

81. Pockros P, Jacobson, Boyer T, et al. GI-5005 therapeutic vaccine plus PEG-IFN/ribavirin improves sustained virological response versus PEG-IFN/ ribavirin in prior non-responders with genotype-1 chronic HCV infection. Hepatology. 2010; 52(Suppl. 4):107A.

82. Drane D, Maraskovsky E, Gibson R, et al. Priming of $\mathrm{CD}^{+}$and $\mathrm{CD} 8^{+} \mathrm{T}$ cell responses using a HCV core ISCOMATRIX vaccine: a Phase I study in healthy volunteers. Hum. Vaccin. 2009; 5(3):151-157. [PubMed: 19246990]

83. Kaneko T, Moriyama T, Udaka K, et al. Impaired induction of cytotoxic T lymphocytes by antagonism of a weak agonist borne by a variant hepatitis C virus epitope. Eur. J. Immunol. 1997; 27(7):1782-1787. [PubMed: 9247592]

84. Klade CS, Wedemeyer H, Berg T, et al. Therapeutic vaccination of chronic hepatitis C nonresponder patients with the peptide vaccine IC41. Gastroenterology. 2008; 134(5):1385-1395. [PubMed: 18471515]

85. Wedemeyer H, Schuller E, Schlaphoff V, et al. Therapeutic vaccine IC41 as late add-on to standard treatment in patients with chronic hepatitis C. Vaccine. 2009; 27(37):5142-5151. [PubMed: 19559112]

86. Firbas C, Boehm T, Buerger V, et al. Immunogenicity and safety of different injection routes and schedules of IC41, a hepatitis C virus (HCV) peptide vaccine. Vaccine. 2010; 28(12):2397-2407. [PubMed: 20060945]

87. Klade, CS.; von Gabain, A.; Manns, MP. Significant continuous viral load decline in treatmentnaive HCV genotype 1 patients after therapeutic peptide vaccination with IC41; Programs and 
Abstracts of the 60th Annual Meeting of the American Association for the Study of Liver Diseases (AASLD 2009); Boston, MA, USA. October 30-November 1 2009; Abstract 1558

88. Rossignol JF. Thiazolides: a new class of antiviral drugs. Expert Opin. Drug Metab. Toxicol. 2009; 5(6):667-674. [PubMed: 19442032]

89. Rossignol JF, Elfert A, El-Gohary Y, Keeffe EB. Improved virologic response in chronic hepatitis C genotype 4 treated with nitazoxanide, peginterferon, and ribavirin. Gastroenterology. 2009; 136(3):856-862. [PubMed: 19135998]

90. Yutani S, Komatsu N, Shichijo S, et al. Phase I clinical study of a peptide vaccination for hepatitis $\mathrm{C}$ virus-infected patients with different human leukocyte antigen-class I-A alleles. Cancer Sci. 2009; 100(10):1935-1942. [PubMed: 19604246]

91. Yutani S, Yamada A, Yoshida K, et al. Phase I clinical study of a personalized peptide vaccination for patients infected with hepatitis $\mathrm{C}$ virus $(\mathrm{HCV}) 1 \mathrm{~b}$ who failed to respond to interferon-based therapy. Vaccine. 2007; 25(42):7429-7435. [PubMed: 17845828]

92. Gowans EJ, Roberts S, Jones K, et al. A Phase I clinical trial of dendritic cell immunotherapy in HCV-infected individuals. J. Hepatol. 2010; 53(4):599-607. [PubMed: 20667615]

93. Davis BS, Chang GJ, Cropp B, et al. West Nile virus recombinant DNA vaccine protects mouse and horse from virus challenge and expresses in vitro a noninfectious recombinant antigen that can be used in enzyme-linked immunosorbent assays. J. Virol. 2001; 75(9):4040-4047. [PubMed: 11287553]

94. Boyer JD, Robinson TM, Kutzler MA, et al. Protection against simian/human immunodeficiency virus (SHIV) 6P in macaques after coimmunization with SHIV antigen and IL-15 plasmid. Proc. Natl Acad. Sci. USA. 2007; 104(47):18648-18653. [PubMed: 18000037]

95. Chong SY, Egan MA, Kutzler MA, et al. Comparative ability of plasmid IL-12 and IL-15 to enhance cellular and humoral immune responses elicited by a SIVgag plasmid DNA vaccine and alter disease progression following SHIV(6P) challenge in rhesus macaques. Vaccine. 2007; 25(26):4967-4982. [PubMed: 17335943]

96. Boyer JD, Robinson TM, Kutzler MA, et al. SIV DNA vaccine co-administered with IL-12 expression plasmid enhances CD8 SIV cellular immune responses in cynomolgus macaques. J. Med. Primatol. 2005; 34(5-6):262-270. [PubMed: 16128921]

97. Sallberg M, Frelin L, Weiland O. DNA vaccine therapy for chronic hepatitis C virus (HCV) infection: immune control of a moving target. Expert Opin. Biol. Ther. 2009; 9(7):805-815. [PubMed: 19527105] •• An in-depth review specifically examining DNA vaccine therapy for $\mathrm{HCV}$.

98. Wang B, Boyer J, Srikantan V, et al. DNA inoculation induces neutralizing immune responses against human immunodeficiency virus type 1 in mice and nonhuman primates. DNA Cell Biol. 1993; 12(9):799-805. [PubMed: 8216851]

99. Davis HL, Whalen RG, Demeneix BA. Direct gene transfer into skeletal muscle in vivo: factors affecting efficiency of transfer and stability of expression. Hum. Gene Ther. 1993; 4(2):151-159. [PubMed: 8494924]

100. Yang NS, Burkholder J, Roberts B, Martinell B, McCabe D. In vivo and in vitro gene transfer to mammalian somatic cells by particle bombardment. Proc. Natl Acad. Sci. USA. 1990; 87(24): 9568-9572. [PubMed: 2175906]

101. Roy MJ, Wu MS, Barr LJ, et al. Induction of antigen-specific CD8 ${ }^{+} \mathrm{T}$ cells, $\mathrm{T}$ helper cells, and protective levels of antibody in humans by particle-mediated administration of a hepatitis B virus DNA vaccine. Vaccine. 2000; 19(7-8):764-778. [PubMed: 11115698]

102. Mathiesen I. Electropermeabilization of skeletal muscle enhances gene transfer in vivo. Gene Ther. 1999; 6(4):508-514. [PubMed: 10476210]

103. Gronevik E, Mathiesen I, Lomo T. Early events of electroporation-mediated intramuscular DNA vaccination potentiate Th1-directed immune responses. J. Gene Med. 2005; 7(9):1246-1254. [PubMed: 15822067]

104. Peng JL, Zhao YG, Mai JH, et al. Non-cytolytic antigen clearance in DNA-vaccinated mice with electroporation. Acta Pharmacol. Sin. 2007; 28(7):1024-1030. [PubMed: 17588339]

105. Sallberg, M.; Frelin, L.; Diepolder, H., et al. A first clinical trial of therapeutic vaccination using naked DNA delivered by in vivo electroporation shows antiviral effects in patients with chronic 
hepatitis C; Presented at: 44th Annual Meeting of the European Association for the Study of the Liver; Copenhagen, Denmark. 23-26 April 2009;

106. Alvarez-Lajonchere L, Shoukry NH, Gra B, et al. Immunogenicity of CIGB-230, a therapeutic DNA vaccine preparation, in HCV-chronically infected individuals in a Phase I clinical trial. J. Viral Hepat. 2009; 16(3):156-167. [PubMed: 19017255]

107. Habersetzer, F.; Zarski, J-P.; Leroy, V., et al. A novel vectorized HCV therapeutic vaccine (TG4040): results of a Phase I study in naive patients chronically infected by HCV; Presented at: 44th Annual Meeting of the European Association for the Study of the Liver; Copenhagen, Denmark. 23-26 April 2009;

108. Kao JH, Chen DS. Global control of hepatitis B virus infection. Lancet Infect. Dis. 2002; 2(7): 395-403. [PubMed: 12127351]

109. Hilleman MR. Overview of the pathogenesis, prophylaxis and therapeusis of viral hepatitis B, with focus on reduction to practical applications. Vaccine. 2001; 19(15-16):1837-1848. [PubMed: 11228353]

110. Vollmer J. Progress in drug development of immunostimulatory CpG oligodeoxynucleotide ligands for TLR. Expert Opin. Biol. Ther. 2005; 5(5):673-682. [PubMed: 15934842]

\section{References}

Websites

201. Efficacy and Safety Study of PEG-rIL-29 Plus Ribavirin to Treat Chronic Hepatitis C Virus Infection (EMERGE). http://clinicaltrials.gov/ct2/show/NCT01001754

202. Phase I Hepatitis C Vaccine Trial of Virosome-formulated Peptides. http://clinicaltrials.gov/ct2/ show/NCT00445419

203. Efficacy of the Therapeutic Vaccine TG4040 Combined With Pegylated Interferon and Ribavirin in Chronic HCV Patients (HCVac). http://clinicaltrials.gov/ct2/show/NCT01055821

204. A Study of a New Candidate Vaccine Against Hepatitis C Virus (HCV). http://clinicaltrials.gov/ ct2/show/NCT01070407 


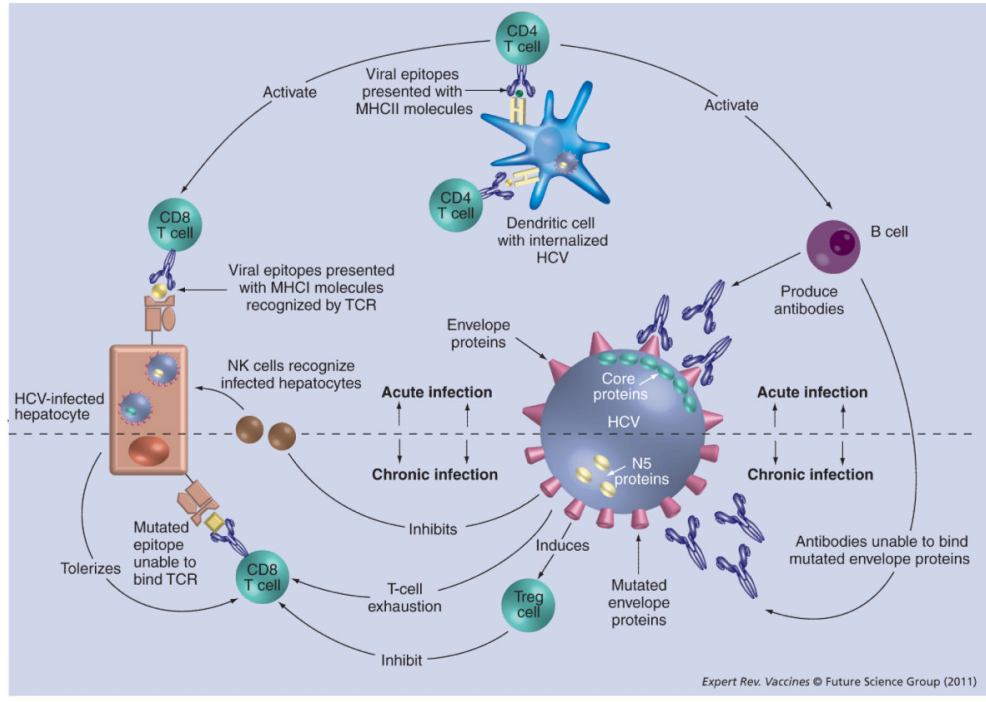

Figure 1. Viral-host immune interactions during acute and chronic $\mathrm{HCV}$ infection HCV: Hepatitis C virus; TCR: T-cell receptor. 


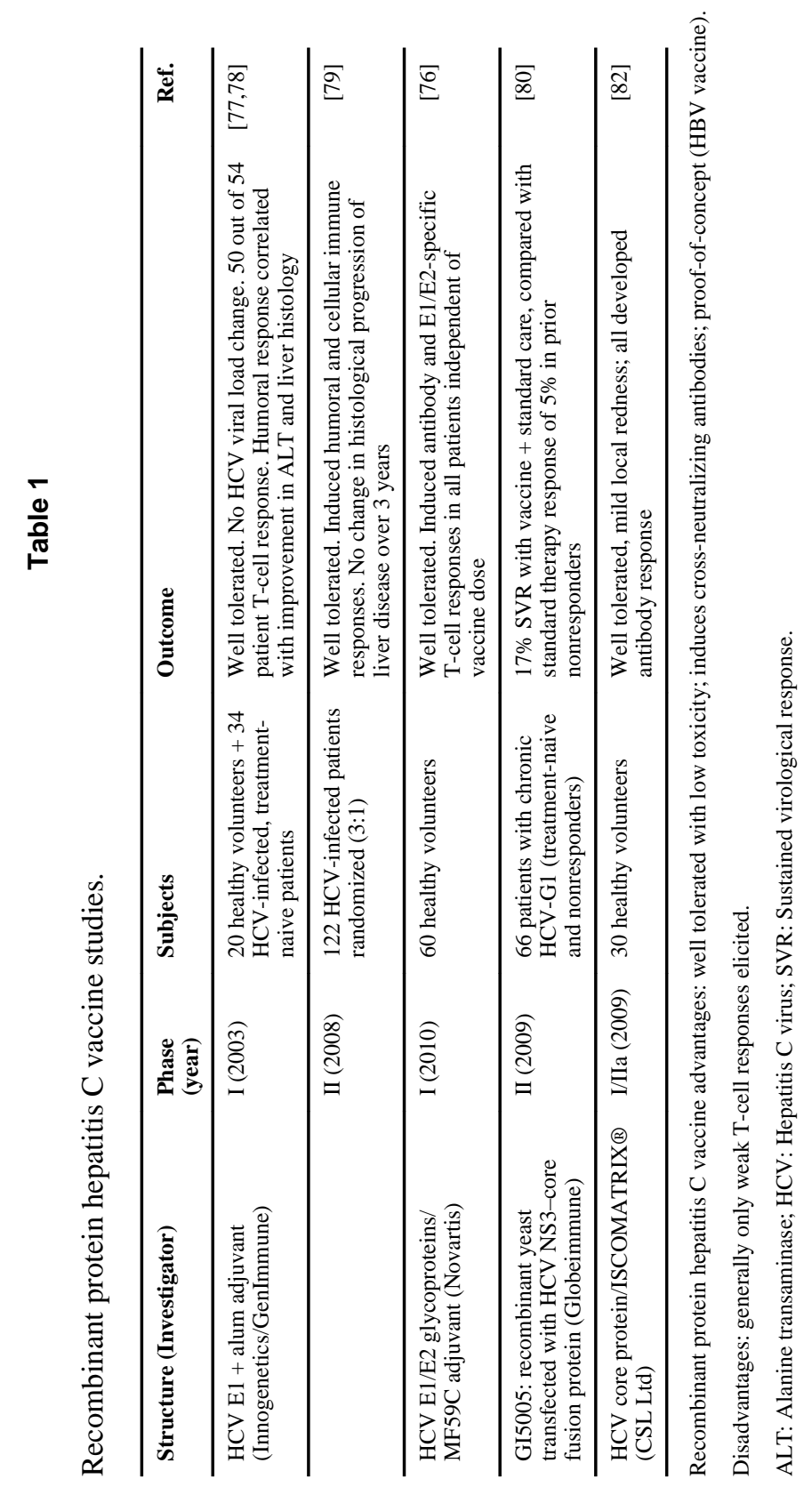

Expert Rev Vaccines. Author manuscript; available in PMC 2011 November 01. 


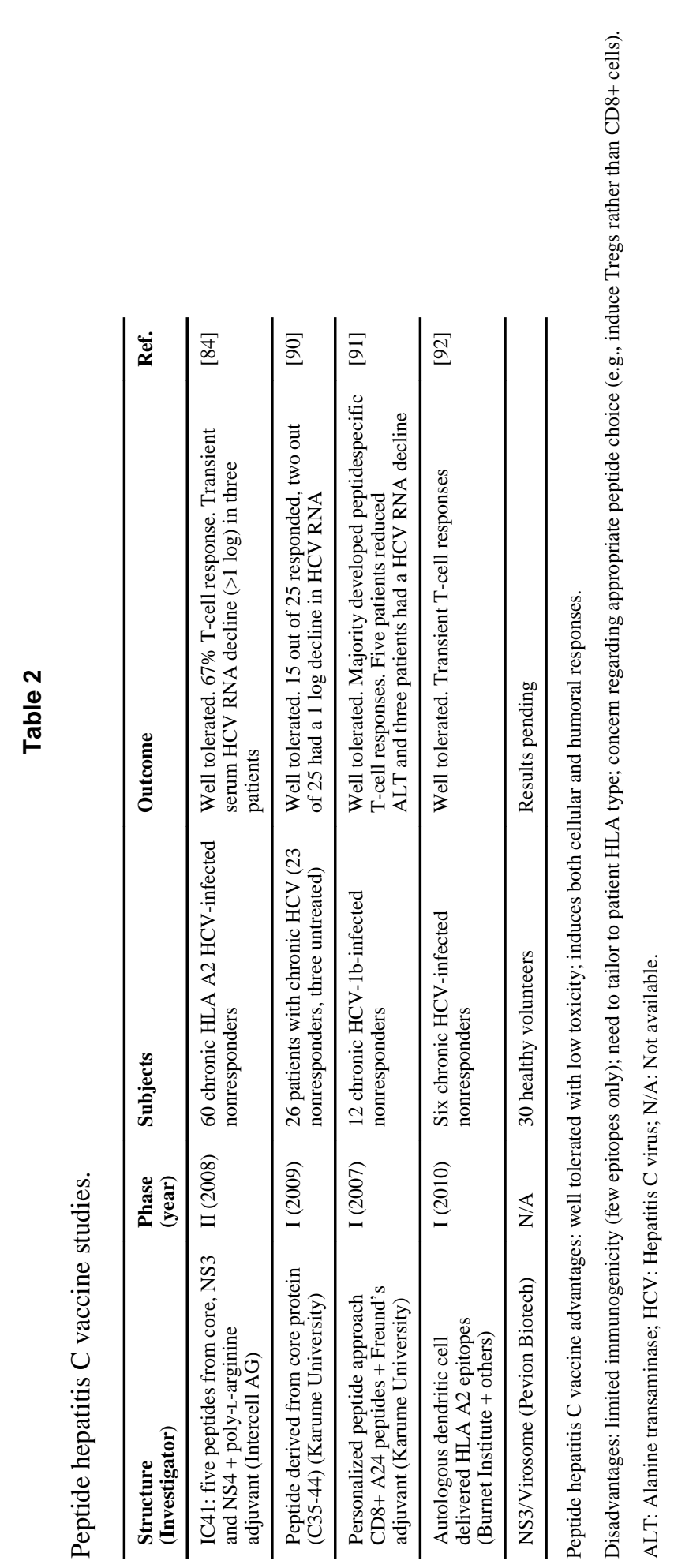

Expert Rev Vaccines. Author manuscript; available in PMC 2011 November 01. 


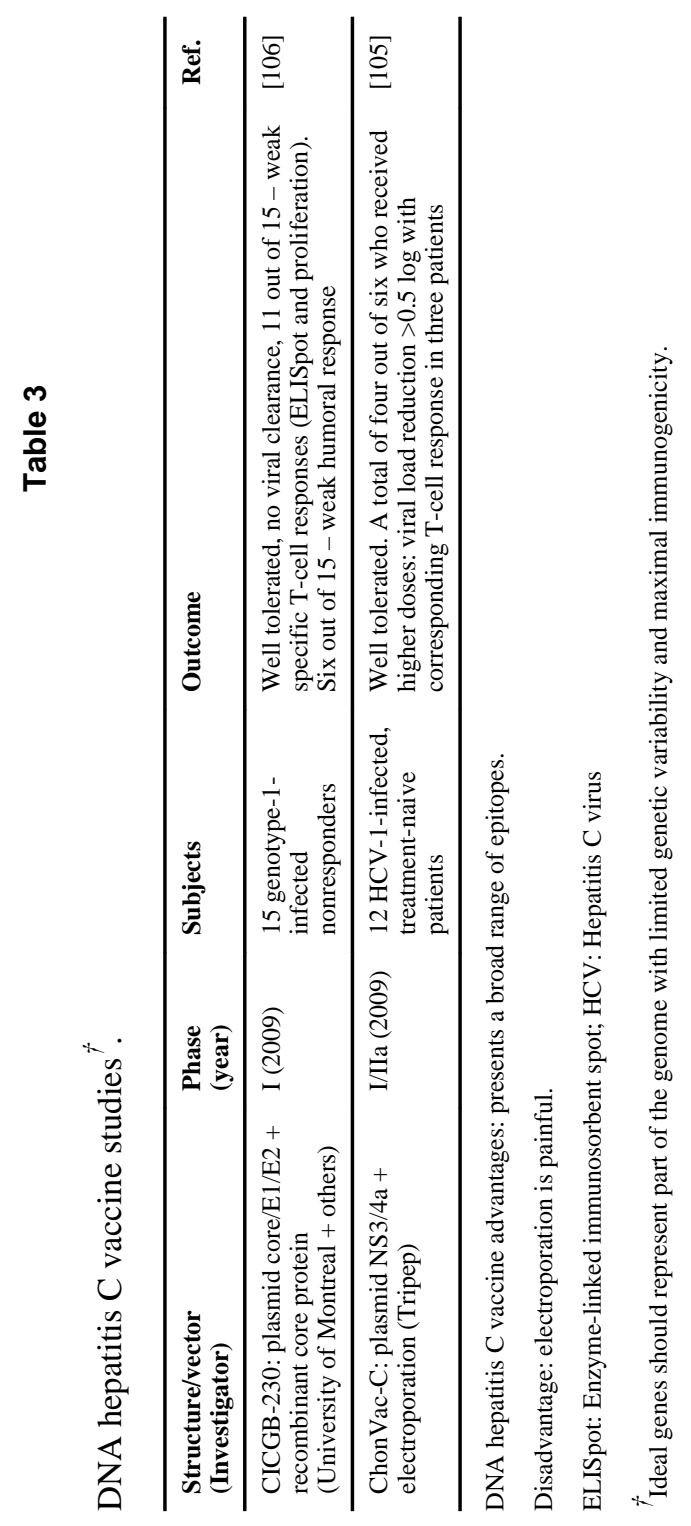

Expert Rev Vaccines. Author manuscript; available in PMC 2011 November 01. 


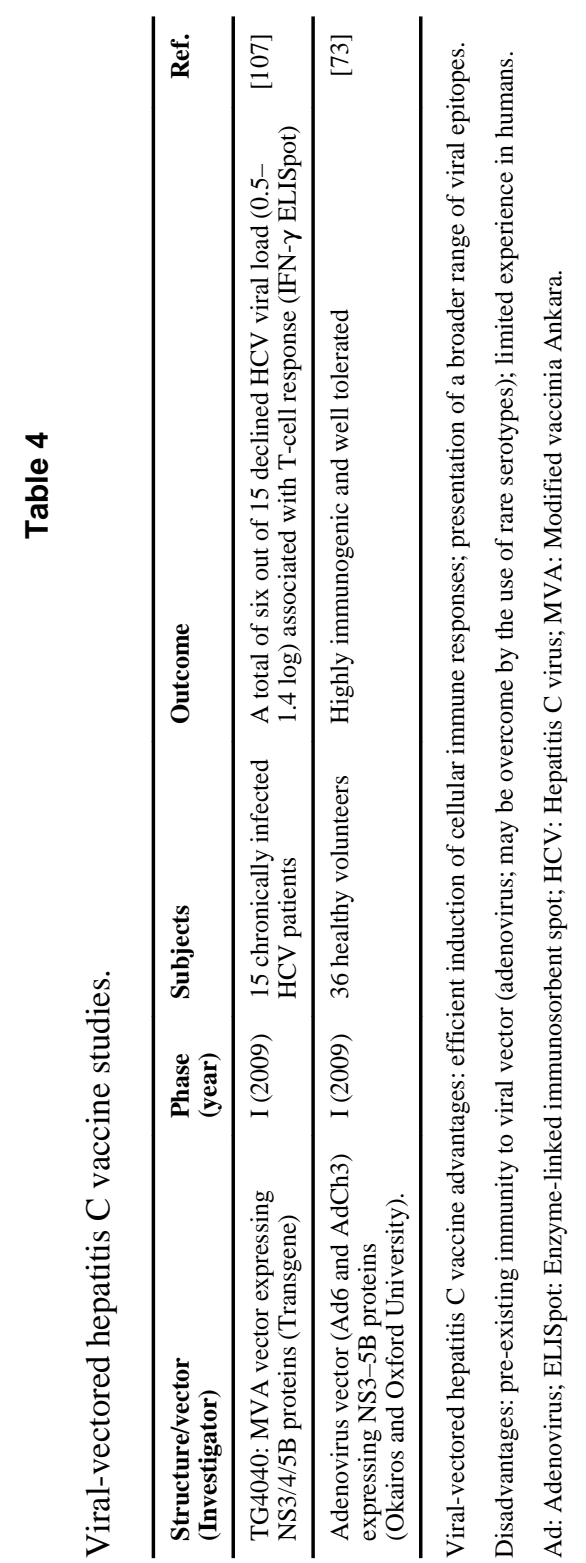

Expert Rev Vaccines. Author manuscript; available in PMC 2011 November 01. 